\title{
Financial Performance Analysis of Distressed Banks in Ghana: Exploration of Financial Ratios and Z-score
}

\author{
Juabin Matey \\ Divass Consult, Ghana \\ mgoodluck369@gmail.com
}

https://orcid.org/0000-0002-6912-7048

\begin{abstract}
A robust bank industry is a major player in the stability of an economy. By way of financial ratios and Z-score, the study analysed UT Bank's financial performance prior to the recent bank sector reforms in Ghana. Annual financials over a ten year period (2007-2016) were used. Debt management practices of UT Bank per the results obtained were quite on the hind side. Leverage and risk variables were poorly handled. Inability to meet creditors' claims would have been eminent considering the average mean values of debt-to-assets and debt-to equity ratios of 0.76 and 0.90 respectively. The entire bank sector will be put on a sound footing if credit management practices of individual banks are refreshed. The bank industry regulator should tighten its supervisory and monitoring role over banks to help detect early signs of non-performing banks. The study further recommends that statutory lending limits of banks be re-enforced to uphold the threshold of 10 percent for unsecured loans and 25 percentage for secured loans of net owned funds of the bank.
\end{abstract}

JEL classification: G01, G2, G21, G28, G33, M41

Keywords: Bank, Debt, Distress, Performance, Credit Management Practice, Z-score 


\subsection{INTRODUCTION}

\subsection{Background to the Study}

I will want to agree by now the world's most great economists are glued to one another trying to find answers to inevitable questions about the sporadic bank industry crisis across the global economy. These crises have had fragmented consequence on individual economies depending on how the macro economy is run with its spill-overs. There have been reported cases of bank mergers, take-overs and consolidations, even in the more cherished advanced economies where risk management practices are presumed to gain prominence.

Torna and DeYoung (2013) have followed sequence of bank instability and closures across the globe and have revealed that an estimated 10 percent of U.S. commercial banks are said to have failed between the early 80 s and 90 s. These disturbing occurrences have not spared the European Central Bank where 25 out of 130 largest Eurozone banks failed a distress test (Tassev, 2019). Central Bank of Nigeria (CBN) closed down 21 banks between 1930 and 1958 due to leverage issues and high risk taking resulting into debt to asset and equity challenges (CBN Bulletin, 2010). A similar exercise was replicated in Kenya, where the Imperial Bank, Dubia Bank and the Chase Bank were closed down for various reasons of non-performing loans, liquidity, credit risk mismanagement and capital deficiency (Taboi, 2017).

Over the immediate past few years, the Ghana bank industry has had its portion of these crises resulting into loss of about 2,700 jobs with an estimated debt pile of 1.7 US dollars (Nyalatorgbi, 2019). The governor of Bank of Ghana (BoG), Dr. Ernest Ad-dison, attributed the crises to poor banking practices, weak supervision and regulation by the immediate past administration of the Central Bank. Most affected banks were found to have exceeded their regulatory single obligor limits, the governor revealed. For instance the UT 
Bank exceeded its single obligor limit of $\mathrm{GH} \not 20 \mathrm{~m}$ when it advanced a loan of GH300m to a politically exposed customer, the governor added (Nyalatorgbi, 2019). Apart from the aforementioned, uncertainties surrounding shareholder funds raised suspicions (Ghana Banking Survey, 2019).

The Banks and Special Deposit-Taking institutions Acts 2016 (Act 930), Section 62 of Ghana has a legal lending limit which demands that beyond a certain threshold of unimpaired capital and surplus accounts, the bank is not permitted to grant to a single customer. This requirement is meant to reduce the risk exposure of a single customer. It further emphasises; depending on whether such a loan is secured or unsecured, it must not exceeding 10 percent of net owned funds of the bank in the case of an unsecured loan and not more than 25 percent if a loan is collateralized (see Abor et al, 2019).

Ghanaian banks which suffered these crises showed early symptoms of distress when they started depending heavily on emergency financial facilities from the regulator to meet depositors' withdrawals. After the crises, it was established that, certain banks never provided collateral before liquidity support was given them and that these funds were eventually misapplied (Nyalatorgbi, 2019). The governor of BoG noted that, Uni-Bank for instance, loaned out an undisclosed sum to Belstar Capital Ltd to acquire shares in Agricultural Development Bank. This move was to facilitate Uni-Bank's bid to becoming the third largest stockholder of Agricultural Development Bank. Over zealous equity owners of banks coupled wit internal wrangling with bank managers over risk taking threshold and neglect of best risk management practices are central to most banks' distress situations. 
An estimated GH860m and GH620m in liquidity support were given to the UT Bank and Capital Bank respectively in 2015 by the BoG to help strengthen their operations. Added to these revelations, issues of rising non-performing loans and capitalisation challenges eventually compelled the central bank to unleash the inevitable measures to salvage the deposits of unsuspecting customers (Nyalatorgbi, 2019). The reports further states; between 2015 and 2018, UniBank took an estimated GH3.1bn, of which more than half the amount was uncollateralized exposing the central bank itself to naked risk. All these shortfalls not withstanding, closures, mergers and takeovers of certain banks are perceived to be politically motivated and rashly executed. This study was undertaken to indeed accept or otherwise of the general null hypothesize of the society.

\subsection{REVIEW OF RELATED LITERATURE}

In embarking on the bank reforms, the Central Bank of Ghana considered a number of parameters that pointed to non-performance. The profit structure relationship is one of available theories linked to bank performance as it has attracted much attention in the industrial sector and the bank industry for that matter. Berger (1995) identifies two competing theories that explain the positive relationship between bank performance on one side and market power and efficient structure theories on the other.

\subsection{The Market Power-Theory vs. Efficient Structure Theory}

Two hypotheses are linked to the market-power theory; the traditional structureconduct-performance and the relative market hypotheses. The traditional structure conduct performance (SCP) occurs where higher loan rates are determined by more concentrated market. This, Aguenaous, Lahreech and Bounnakaya (2017) explain; with the tightened up of industry entry requirements, firms are forced to improve efficiency in service delivery or allow for normal distribution of efficiency. Due to association discipline, banks can collude, 
reminiscent of high level of their concentration to reduce deposit rates. Similarly, interest on lending could be increased to enjoy relatively high profits due to same advantage of highly concentrated firms. There are cited failed attempts to establish a significant link between market structure and bank's efficiency. Though other studies have established a positive correlation between market structure and bank performance, they were weak (Aguenaous et al, 2017). In the case of Kaufman (1966), he found a non-linear relationship between those two variables (market structure and bank performance). Their findings (Smirklock, 1985; Rhodes; 1985) were not contrary to Kaufman's (1966).

The efficiency theory is decomposed into the X-efficiency and the Scale-efficiency hypotheses. The E-efficiency hypothesis is inclined to the view that, bank managers who best utilise their scarce resources efficiently enjoy high profits. In this situation, this calibre of management is able to operate at lower cost per unit service. In the case of the Scale-efficient hypothesis, instead of having efficiency as a control variable, volume of operation is central in their argument. Those banks that have the ability to operate on large scale tend to do so at lower cost per service translating into higher profits (Berger, 1995). Seelanatha (2010) studied bank's profitability using these theories. He found performance to have a high dependency on bank's efficiency as opposed to market structure.

A pethora of researchers had challenges with the use of market share as a function of efficiency (see Berger, 1995; Shepherd, 1986; Seelanatha, 2010; cited in Aguenaous et al, 2017). Other available empirics on bank performance measures, Sheikh-Waqas (2005) found a positive relationship between debt-to-equity, equity multiplier and bank's insolvency risk. In their study of financial ratio approach to evaluating financial performance, Attefah and Darko (2016) realised that debt-to-equity, debt-to-asset and equity multiplier positively influence bank risk, insolvency and instability. 


\subsection{METHODOLOGY}

This study adopts a panel data analysis to test bank stability and probability of insolvency using financial ratios and Z-score (see Srairi, 2013; Lepetit, Nya, Rous \& Tarazi, 2008; Altman, 1968). Specifically, the study looks at how justifiably distressed certain banks in the midst of the current financial turbulence were in Ghana. The UT Bank Ghana is a case under consideration, as I seek to investigate its stability and insolvency, using its published financials between 2007 and 2016.

Return on Assets (RoA) is the basic variable that is traditional in computing the Zscore. RoA is computed by taking the balance sheet figure of income after tax dividing this by the value of average Total Assets over an accounting year. The Z-score is also arrived at by taking the mean of RoA combined with Capital-to-Assets Ratio (Equity/Total Assets) further divided by the standard deviation of RoA.

$R o A Z-$ Sore $=\frac{\mu(R o A)+(C A P A R)}{\sigma(R o A)}$

It must be stressed that, equity capital to asset ratio is computed using only shareholders' equity, subordinated debt exclusive (Li, Tripe \& Malone, 2017). 
Table 1: Correspondence between the Z-score and Standard and Poor' Rating

\begin{tabular}{|c|c|c|c|c|c|}
\hline \multirow[t]{4}{*}{ Interpretation } & Rating & $\begin{array}{l}\text { Zth-score } \\
\text { Threshold }\end{array}$ & Rating & $\begin{array}{l}\text { Zth-score } \\
\text { Threshold }\end{array}$ & Interpretation \\
\hline & AAA & $>8.15$ & $\mathrm{BB}+$ & 5.65 & \\
\hline & $\mathrm{AA}+$ & 8.15 & $\mathrm{BB}$ & 5.25 & \\
\hline & $\mathrm{AA}$ & 7.6 & BB- & 4.95 & Grey Area \\
\hline \multirow[t]{7}{*}{ Safe Area } & AA- & 7.3 & $\mathrm{~B}+$ & 4.75 & \\
\hline & $\mathrm{A}+$ & 7 & $\bar{B}$ & 4.4 & \\
\hline & A & 6.85 & B- & 4.15 & \\
\hline & A- & 6.65 & $\mathrm{CCC}+$ & 3.75 & \\
\hline & $\mathrm{BBB}+$ & 6.4 & $\mathrm{CCC}+$ & 3.2 & Distress Area \\
\hline & $\mathrm{BBB}+$ & 6.25 & $\mathrm{CCC}-$ & & \\
\hline & BBB- & 5.85 & $\mathrm{D}$ & & \\
\hline
\end{tabular}

Source: Altman and Hotchkiss (2006, p.314)

For purposes of a double check, the study considered the Z-score Plus model proposed by Altman (2006) for evaluating corporate credit which was tested to have had between $70 \%$ 95\% accuracy and reliability at different periods. Accordingly, a bank is most likely to go insolvent or bankrupt if its Z-score falls below 1.8, while companies with a Z-score above 3.0 are deem to be in good standing and therefore likely not to go bankrupt. Companies within the region of 1.8 and 3.0 are said to operate in the grey area and that bankruptcy is as likely as not. 


$$
Z_{1}=1.2 \beta_{1}+1.4 \beta_{2}+3.3 \beta_{3}+0.6 \beta_{4}+1.0 \beta_{5}
$$

Where

$\beta_{l}=$ Net Working Capital divided by Total Assets (WC/TA)

$\beta_{2}=$ Retained Earnings for the year divided by Total Assets (RE/TA)

$\beta_{3}=$ Earnings before Interest and Tax divided by Total Assets (EBIT/TA)

$\beta_{4}=$ Market Value of Shareholders' Equity divided by Book Value of Total Liabilities

(MVE/TL)

$\beta_{5}=$ Revenue divided by Total Assets

Table 2: Classification according to Altman (1993) Z-score

\begin{tabular}{|c|c|c|c|}
\hline Z-score & Safe Zone & Gray Zone & Distress Zone \\
\hline \multicolumn{4}{|l|}{ Initial Model } \\
\hline Z-score $<1.81$ & & & $\sqrt{ }$ \\
\hline $1.81<$ Z-score $<2.99$ & & $\sqrt{ }$ & \\
\hline Z-score $>2.99$ & $\sqrt{ }$ & & \\
\hline \multicolumn{4}{|l|}{ Revised Model } \\
\hline Z-score $<1.1$ & & & $\sqrt{ }$ \\
\hline $1.1<$ Z-score $<2.66$ & & $\sqrt{ }$ & \\
\hline Z-score $>2.66$ & $\sqrt{ }$ & & \\
\hline
\end{tabular}

Adopted from Alman (2006) 


\subsection{RESULTS AND ANALYSIS}

The researcher analysed the financial performance of defunct UT Bank Limited between 2007 and 2016 using a number of bank stability and insolvency measures. The study was limited to only UT Bank Limited due to unavailability of published financials of other banks that suffered same fate, on which to base my conclusion.

The then Unique Trust Bank (now UT Bank) Ltd was rebranded in May 2009 and got listed into the Ghana Stock Exchange in 2010 under the brand name UTB. It was one of privately owned indigenous commercial banks in Ghana prior to the takeover by GBC Bank in August 2017. In order to compare average performance selected variables over ten (10) years, analysis was done under two headings; Risk and Leverage / stability and solvency.

\subsection{Risk and Leverage Measurement Ratios}

\subsubsection{Debt-to-Equity-Ratio (DER)}

DER measures long term financial stability of commercial entities. It looks at external claims against the bank relative to its shareholder equity. It looks at claims of creditors and depositors over bank assets, in our situation. Though controversial, higher DER is panacea for insolvency and likelihood of failure. 
Table 3: Bank Level Stability Variable Performance

\begin{tabular}{lrrrrrrrrrrrrl}
\hline & $\mathbf{2 0 0 7}$ & $\mathbf{2 0 0 8}$ & $\mathbf{2 0 0 9}$ & $\mathbf{2 0 1 0}$ & $\mathbf{2 0 1 1}$ & $\mathbf{2 0 1 2}$ & $\mathbf{2 0 1 3}$ & $\mathbf{2 0 1 4}$ & $\mathbf{2 0 1 5}$ & $\mathbf{2 0 1 6}$ & $\boldsymbol{\mu}$ & O & CV \\
\hline DER & 5.83 & 6.54 & 8.1 & 9.1 & 10.6 & 6.7 & 9.4 & 10.8 & 4.8 & 4.5 & 7.6 & 2.30 & 3.3 \\
EM & 6.8 & 7.6 & 9.1 & 10.1 & 11.6 & 7.7 & 10.4 & 11.8 & 5.8 & 5.5 & 8.6 & 2.30 & 3.8 \\
DAR & 0.85 & 0.86 & 0.89 & 0.9 & 0.91 & 0.87 & 0.9 & 0.91 & 0.83 & 0.82 & 0.9 & 0.03 & 26.4 \\
\hline
\end{tabular}
Source: Author's own computation from bank financials (2007-2016)

It is realised that (Table 3), an average mean score of 7.6 over the ten year period was recorded in terms DER. One of the implications is, UT Bank's creditors provided 0.76 out of every cedi financed by the bank. In an unlikely event where assets value declines, it will have the potency of damaging lenders, since they have preferential rights of payment. In fact, it's unsafe to go beyond 50\% DER threshold. That is, a bank should finance 0.5 of every $\mathrm{GH} \notin 1$ (Creditors bear 0.5). Equity owners are comfortable when high DER values. The reverse is true of lenders and depositors. Lenders tend to interfere with the management of the bank due to higher DER which allows them a higher stake in financial decisions either directly or otherwise.

Banks that are associated with high DER values tend to have lower borrowings rights, even in emergencies, since financial ratios play a very key role in how businesses fair. In worst scenarios, the central regulatory body could interfere in borrowing arrangements of banks that have higher DER. The results of UT Bank appear to defeat the purpose of the Eefficiency theory when it posits that bank managers who best utilise their scarce resources efficiently enjoys high profits, thereby will enjoy continuity. 


\subsubsection{Equity Multiplier (EM)}

Equity Multiplier (EM) is one of financial leverage ratios which a representation of the proportion of bank's assets financed by shareholders relative to lenders. It is estimated that, about 70-90 percent of banks' assets is tied to loans and advances (Koflowits, 2019). Table 2 shows that 8.6 percent of UT Bank's assets were financed by owners' equity as against 1.4 percent financed by lenders/customers' deposits. A higher EM value draws the bank to risk of failure (Sheikh-Wagas, 2005). That perhaps would have gratified investors because UT Bank used more equity to purchase assets than they used debt. To finance assets purchase. It must quickly be stressed that, a higher equity rations sometimes could be a strategy used by the bank to look profitable so as to purchase assets at a low cost.

Traditionally, a higher EM is not a safe place for a bank to stay inn, and very risky as it is an unhealthy practice and serves as a conduit for discontinuity. A trigger of high default by customers or debtors to the bank in the form of non-performing loans, UT Bank had a high tendency to invite distress or a feverish stability.

\subsubsection{Debt-to-Asset-Ratio (DAR)}

This ratio measures an organisation's ability and strength to meet claims by creditors using company's own resources. Higher DAR values signify increased in insolvency risk. Creditors have more claims on the banks financial and non-financial resources should the inevitable happen. Per the results, ownership of the bank literary rested with creditors. A look at UT Bank's mean average of DAR which is pegged at 0.9 , out of every GH $\not 1$ ownership claim by UT Bank, only 0.1 pesewa is really owned terms in real assets. Efficiency in banking 
sector is paramount if and positively impacts on banks' stability. Seelanatha (2010) studied bank's profitability using the efficiency theories, found better performance and bets management practices to have a high dependency on bank's efficiency. Inefficient banks are associated with high debt ratios.

\subsubsection{Solvency Measurement}

The Z-score has gained wide spread acceptance as a measure the inverse of which gives the probability of insolvency in the bank industry and financial stability literature (Bouvatier, Lepetit, Rehault and Strobel, 2017). I used the RoA-based Z-score and Altman (2012) Z-score Plus to potentially compare capitalisation and returns or variability and returns. This was made possible by the use of accounting data. Table 3 has computed results.

Table 4: Results of Z-scores computed from different Approaches

\begin{tabular}{lccccccccccc}
\hline & 2007 & 2008 & 2010 & 2011 & 2012 & 2012 & 2013 & 2014 & 2015 & 2016 & Average \\
FV-Zscore & 10.6 & 9.4 & 8.3 & 7.6 & 6.8 & 9.4 & 7.4 & 6.8 & 11.8 & 12.3 & 9.04 \\
LN-Zscore & 2.4 & 2.2 & 2.1 & 2.0 & 1.9 & 2.2 & 2.0 & 1.9 & 2.50 & 2.5 & 2.17 \\
$Z_{1}$-score & 1.7 & 1.5 & 1.1 & 0.9 & 0.8 & 1.3 & 1.4 & 1.7 & 1.50 & 1.9 & 1.38 \\
\hline
\end{tabular}

Source: Author's own computation from bank financials (2007-2016)

FV-Zscore represents face value of the Z-score which is used to run the $\mathrm{LN}$-Zscore (natural log of FV-Zscore). The Z-score is known to be highly skewed, as such; the natural $\log$ of the FV-Zscore was used to defuse the likelihood of misleading results. As a result, the researcher dwelled much on the average Z-scores of the two standardised models. With average Z-scores of 2.17 and 1.3 produced from the RoA-based and Altman $\left(\mathrm{Z}_{1}\right)$ respectively, I used Standard and Poor's Ratings Table (Table 1) to form an opinion on the RoA-based Z-score per balance sheet figures. With a score of 2.17, it puts UT Bank under the distress condition, characterised by illiquid assets sensitive to economic downturn. In the case of results from Altman's model $\left(Z_{1}\right)$ an average score of 1.38 was obtained, again places UT Bank in the distress zone (see Table $2 \& 4)$. 


\subsection{Conclusion and Recommendations}

Stability measures of banks and their ability to take risk are very central to determine if they are capable of generating income to meet fixed cost. Uncontrollable rising debt is justifiably a source of concern, especially when used unwisely and without moderation, could spark financial crisis. UT Bank's ability to control its debt to assets, debt to equity and equity multiplier was weak. Per results from its financials and the methodology adopted by the researcher, UT Bank relied heavily on external debt since it was unable to internally generate adequate income to meet its fixed costs and to oblige to claims from creditors; hence $90 \%$ of its resource ownership literally was to creditors.

Major among failed administrative indicators was poor credit risk management which is central to the bank's survival. In fact, working to construct a structure of proper bank corporate practices, debt seemed to have been intractable to management of UT Bank. This certainly will invite discontinuities and challenges in which distress and limitations placed on borrowing were key. Most banks are noted for poor credit management practices and will need to be worked on if the bank industry in Ghana needs to restore clientele confidence. Policymakers should work on reducing systemic risk emanating from high leverage financial system. The researcher further suggests that bank annual financials be published to allow for independent academics do unbiased analysis and draw conclusions. 


\subsection{Limitation of Study}

Better comparison of results would have put conclusion drawn in this study in a more revealing perspective. This shortfall is as a result of unavailability of financials of banks that suffered same fate with UT Bank. This problem of unavailability of data on certain banks is cause for worry, since their audited reports are relied upon to determine corporate performance. No wonder the messy situation got most loyal parties of the industry insinuating latent reasons for exercise by the bank industry regulator. 


\section{REFERENCES}

Abor, J.Y., Gyeke-Dako, A., Fiador, V.O., Agbloyor, E.K., Amidu, M., \& Mensah, L. (2019). Money and banking in Africa loan portfolio and credit management. Advances in African Economic, Social and Political Development, Springer Nature. doi.org/10.1007/978-3-319-77458-9

Aguenaou, S., Lahrec, A., \& Bounakaya, S. (2017). Analyzing banks' efficiency as a measurement of performance in the Moroccan context: Application of CAMEL Framework. International Review of Research in Emerging Markets and the Global Economy, 3 (1), 1105-1121

Altman, E. I. (1968). Financial ratios, discriminant analysis and the prediction of corporate bankruptcy. Journal of Finance, 189-209.

Altman, E.I. \& Hotchkiss, E. (2006). Corporate financial distress \& bankruptcy. $3^{\text {rd }}$ edition. J. Wiley \& Sons. Hoboken, New Jersey

Attefah, E.K, \& Darko, E.A. (2016). Financial ratios approach to evaluating financial performance of Cal Bank Ghana from 2010 to 2014 International Journal of Academic Research in Business and Social Sciences, 6(6), 150-176

Basel Committee on Banking Supervision, BCBS. (2010). Basel III and financial stability. Bank for International Settlement

Berger, A. (1995). The profit-structure relationship in banking - Tests of market-power and efficient-structure hypotheses. Journal of Money, Credit and Banking, 404 420.

Central Bank of Nigeria [CBC] (2010). Annual report bullion; January-march

Ghana Banking Survey (2019). Banking reforms so far: Topmost issues on the minds of bank CEOs. Available at https://www.pwc.com/gh/en/assets/pdf/ghana-banking-survey 2019.pdf. Retrieved on 25th October, 2019

Kaufman, G. (1966). Bank market structure and performance: The evidence from Iowa. Southern Economic Journal, 429-439. 
Lepetit, L., Nys, E., Rous, P. \& Tarazi, A. (2008). Bank income structure and risk: An empirical analysis of European banks. Journal of Banking and Finance, 32(8), 1452-1467

Li, X., Tripe, D., \& Malone, C. (2017). Measuring bank risk: An exploration of z-score

Prakash, P., Iqbal. T. H., Jennifer, M. Q., \& Nympha, R.J. (2017). Capital Structure and Financial Performance of Banks, International Journal of Applied Business and Economic Research, 15(23), 300-312

Nyalatorgbi, E. (2019). Bank of Ghana closes seven banks in banking crisis: African Agenda, Third World Network Africa, 21(3), 33-36

Rhoades, S. (1985). Market share as a source of market power: Implications and some evidence. Journal of Economics and Business, 3 (4), 343-355.

Seelanatha, L. (2010). Market structure, efficiency and performance of banking industry in Sri Lanka. Banks and bank systems, 5(1), 65-75

Sheikh Waqas, A. (2005). Financial statement analysis of bank, Falah. Virtual University Pakistan, Pakistan

Shepherd, W. (1986). Tobins'q and the structure-performance relationship: Comment. The American Economic Review, 76(5), 1205-1210

Smirlock, M. (1985). Evidence of the (non) relationship between concentration and profitability in banking. Journal of Money, Credit and Banking, 17(1), 69-74.

Srairi, S. (2013). Ownership structure and risk-taking behaviour in conventional and Islamic banks: Evidence for MENA countries. Borsa Istanbul Review, 13(4)

Taboi, L. (2017). How the Kenyan banks went under African Business.

Tassev, L. (2019). Three bank failures open new chapter in never-ending financial crisis

Torna, G. \& DeYoung, R., (2013). Nontraditional banking activities and bank failures during the financial crisis. Journal of Financial Intermediation 22, 397 421 